\title{
ARAŞTIRMA/RESEARCH
}

\section{SAĞLIK YÜKSEKOKULU HEMŞİRELIK BÖLÜMÜ ÖĞRENCILERINIIN STRES DURUMLARI VE STRESLE BAŞ ETME YÖNTEMLERİ}

\section{Canan BİRIMOĞLU OKUYAN* Ebru DEVECI***}

\begin{tabular}{ccc}
\hline Alınış Tarihi/Received & Kabul Tarihi/Accepted & Yayın Tarihi/Published \\
12.10 .2018 & 14.05 .2020 & 30.06 .2020 \\
\hline
\end{tabular}

Bu makaleye atıfta bulunmak için/To cite this article:
Birimoğlu Okuyan C, Deveci E. Sağlı yüksekokulu hemşirelik bölümü öğrencilerinin stres durumları ve
stresle baş etme yöntemleri. Anadolu Hemşirelik ve Sağlı Bilimleri Dergisi, 2020;23(2):205-211.
DOI: 10.17049 /ataunihem.469787

\section{$\ddot{O} Z$}

Amaç: Bu araştırma Sağlık Yüksekokulu Hemşirelik Bölümü ögrencilerinin stres durumları ve stresle baş etme yöntemlerini belirlemek amacı ile yapılmıştır.

Yöntem: Tanımlayıcı nitelikte yapılan araştırmanın evrenini bir üniversitenin hemşirelik bölümü ögrencileri oluşturmuştur (N=460). Evrenin tamamına ulaşılmaya çalışılmış olup 320 ögrenci araştırmaya dahil edilmiştir. Veriler anket formu, Hemşirelik Ĕgitimi Stres Ölçeği ve Başa Çıkma Stratejileri Ölçeği ile toplanmıştır. Verilerin analizinde sayl, yüzde, ortalama, standart sapma, t testi ve tek yönlü varyans analizi kullanılmıştır.

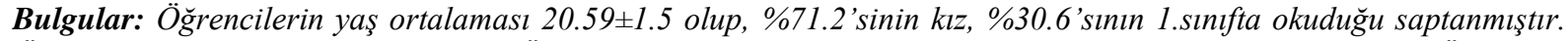
Ögrencilerin hemşirelik Eğitimi Stres Ölçeği ortalama puanının $63.4 \pm 17.3$ olduğu, Başa Çıkma Stratejileri Ölçeği alt

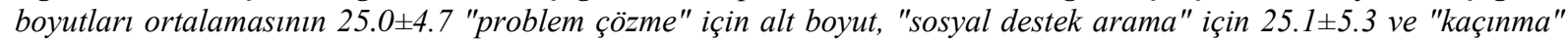
için 24.2 \pm 5.3 olduğu saptanmıştır. Cinsiyeti kadın olan, İkinci sinıf öğrencilerinin ve hemşirelik bölümünü isteyerek seçmeyen ögrencilerin Hemşirelik Ĕ̆itimi Stres Ölçeği puan ortalamasının anlamlı şekilde daha yüksek olduğu, hemşirelik bölümünü isteyerek seçen ögrencilerin ise problem çözme alt boyut ortalamasının anlamlı şekilde daha yüksek olduğu belirlenmiştir ( $p<0.05$ ).

Sonuç: Hemşirelik ögrencilerinin yüksek düzeyde stres yaşadığ s, săglıklarının korunması ve akademik başarılarının artması için stres oluşturan faktörlerin azaltılmasına yönelik düzenlemelerin yapılması önerilmektedir.

Anahtar Kelimeler: Başa çıkma; Hemşirelik ĕ̆itimi; hemşirelik ögrencisi; stres.

\section{ABSTRACT}

The Methods for Coping with Stress and Stress Situations of Nursing Students in Health School

Aim: This research was conducted with the aim of determining the methods for coping with stress and stress situations of nursing students in health school.

Methods: The universe of the research which has been conducted as descriptive consisted of nursing students of a university $(N=460)$. Sample group was not selected, 320 students who accepted to attend the research included in the study. Data was collected with the interview form prepared by authors, Coping Strategy Indicator and Nursing Education Stress Scale. Data was analysed by numbers, percentage, mean, standard deviation, $t$ test and one way ANOVA.

Results: The average age of the students was $20.59 \pm 1.5,71.2 \%$ of them were girls and $30.6 \%$ of them were at the first grade. Nursing Education Stress Scale mean score of 63.4 \pm 17.3 Sub-dimension means for Coping Strategy Indicator $25.0 \pm 4.7$ for "problem-solving", 25.1 \pm 5.3 for "seeking social support" and $24.2 \pm 5.3$ for "avoidance". It was found that average score of Nursing Education Stress Scale was significantly higher for the students who gender of female and do not voluntarily choose the nursing department at 2 st grade whereas the students who voluntarily selected the nursing department had significantly higher problem solving sub-dimension averages $(p<0.05)$.

Conclusions: Our results have shown that nursing students experience high stress. Therefore, it is recommended to make arrangements to reduce stress factors in order to protect their health and increase their academic success.

Key words: Coping; nursing education; nursing student; stress.

\footnotetext{
*Sorumlu yazar: Sakarya Uygulamalı Bilimler Üniversitesi Sağlık Bilimleri Fakültesi, Hemşirelik AD, (Dr. Öğr. Üyesi), ORCID ID: 0000-0002-7339-6072, E-posta: cananbirimoglu@ subu@edu.tr

** Hasan Kalyoncu Üniversitesi, Sağlık Hizmetleri Meslek Yüksekokulu, Anestezi Bölümü,(Öğr. Gör.), ORCID ID: 0000-0003-0166-4741, E-posta: ebru.deveci@hku.edu.tr
} 


\section{GİRis}

Sağllğı korumak ve geliştirmek için olumlu sağlık davranışlarının kazanılması ve bu davranışların uygulamaya dönüştürülmesi stres yönetimi açısından önemlidir (1).

Bireyde huzursuzluk ya da gerginlik yaratan stresör/lerin deneyimlenmesi ve bu uyarı/lara verilen tepki olan stres, öğrencinin aile, sosyal ve çalışma hayatını, en önemlisi sağlığını olumsuz etkileyen, tehdit eden bir faktördür. Öğrencinin yaşadığı bu fiziksel ve duygusal faktörler özellikle üniversite dönemine denk gelebilmektedir. Farklı ortama adaptasyon ve alışılmışın dışında yaşam tarzı, rol ve sorumluluklar, başarılı olma kaygısı gibi durumlar üniversite öğrencilerinde strese neden olan faktörlerdendir (2). Öğrencilerde stresin artmasıyla birlikte öğrencilerin akademik başarısı düşmekte ve yaşam kalitesi de olumsuz etkilenmektedir (3-6). Özellikle dikkat gerektiren, uygulamalı öğrenimi kapsayan, gözlem yapmaya gerektiren bir eğitim alan hemşirelik öğrencileri (5) hasta ve hastane ortam1, bireylere bakım verme, hastane ortamina olan adaptasyon sorunları $(7,8)$ gibi faktörlerden dolayı diğer bölümlerde okuyan öğrencilere kıyasla daha fazla stres yaşayabilmektedir (9-11). Maruz kalınan bu stresörler öğrencinin bedenen, ruhen ve sosyal yönden sorunlar yaşamasına neden olmakta ve bu durum öğrencide hastalıklara yol açtığı için çözülmesi ya da yönetilmesi gereken önemli bir faktör olmaktadır. Yapılan bir çalışmaya göre öğrencilerin stres durumunun ortama göre değiştiği belirlenmiştir (11). Karaca ve arkadaşları yaptıkları araştırmalarında bildirdiklerine göre Rhead, hemşirelik okullarında eğitim süreci sırasında yaşanan stresin, öğrencilerin akademik performans ve sağlığını negatif etkilediğini belirtmiştir (5). Bu yüzden öğrencilerin stres ile baş etme yöntemlerini çok kullanmadıkları dolayısıyla stresle baş etme yöntemlerini geliştirmelerine yardımcı olacak yöntemler sunarak onların strese yönelik tepkilerinin güçlendirilmesi ve okul hayatlarındaki stresi en aza indirmek oldukça büyük öneme sahiptir. Diğer bir deyişle, doğru baş etme yöntemlerinin kullanılması, strese uyum sürecinde önemli rol oynamaktadır (12).

Geleceğin meslek üyesi olmaya aday öğrencilerin etkili, uygun ve kaliteli bakımı sağlaması (13) ve bu etkin bakımı mezuniyet sonrasına taşımaları için öğrencilerin stres düzeylerinin belirlenmesi ve stresin olumsuz etkilerinden korunmaları, etkili baş etme stratejilerini kullanabilmeleri bu durumda yapılacak gerekli girişimler açısından ve gelecekteki profesyonel hemşirelik hizmeti açısından son derece önemlidir.

$\mathrm{Bu}$ araştırma, sağlık yüksekokulu hemşirelik bölümü öğrencilerinin stres durumları ve stresle baş etme yöntemlerini belirlemek amacıyla yapılmıştır.

\section{GEREÇ VE YÖNTEM}

Araştırmanın tipi: Tanımlayıcı tipte araştırmadır.

Araştırmanın Evren ve Örneklemi: Araştırmanın evrenini, 2018-2019 eğitim öğretim yılı Hatay Mustafa Kemal Üniversitesi Sağlık Yüksekokulu hemşirelik bölümünde öğrenim gören öğrenciler oluşturmuştur $(\mathrm{N}=460)$. Evrenin tümüne ulaşılmaya çalışılmış olup, Mart-Mayıs 2018 tarihleri arasında araştırmaya katılmayı kabul eden öğrenciler araştırmanın örneklemini oluşturmuştur $(\mathrm{n}=320)$.

Veri Toplama Aracı: Veriler; anket formu, Hemşirelik Eğitimi Stres Ölçeği (HESÖ) ve Başa Çıkma Stratejileri Ölçeği (BSÖ) ile toplanmıştır. Hemşirelik Ĕğitimi Stres Ölçeği (HESÖ): GrayToft ve Anderson (1981) tarafindan geliştirilmiş (13), Karaca ve ark. (2014) tarafından Türkçe'ye uyarlanmıştır (5). 32 madde ve her bir alt boyutu 0-48 arasında olan ölçeğin toplam puanı 0-96 arasındadır ve puanın artması stresin arttı̆̆ına göstermektedir. Bu çalışmada Cronbach alpha iç tutarlık katsayısı .87 olarak bulunmuştur.

Başa Çıkma Stratejileri Ölçeği (BSÖ): Amirkhan (1990) tarafından geliştirilmiş (14), Aysan (2003) (15) tarafindan Türkçeye uyarlama ve geçerlik, güvenirlik çalışması yapılmış bireylerin stres durumlarında başa çıkma stratejilerini kullanma derecesini ölçen kendini değerlendirme aracıdır. Problem çözme, sosyal destek arama ve kaçınma olmak üzere 3 alt boyutu olan ölçeğin, alt ölçek toplam puanları 11 ile 33 arasında değişmektedir. Alt ölçek toplam puanlarının yüksek olması, tanımlanan nitelikteki başa çıkma stratejisinin yüksekliğini göstermektedir. $\mathrm{Bu}$ çalışmada Cronbach alpha iç tutarlık katsayısı .77 olarak bulunmuştur.

Araştırma, Mart-Mayıs 2018 tarihleri arasında araştırmanın amacı açıklanarak öğrencilerin ders dışı zamanlarında araştırmacı gözetiminde ortalama 15-20 dakika süresince uygulanmıştır.

Verilerin Değerlendirilmesi: Araştırmada elde edilen veriler SPSS 22.0 (Statistical Package of Social Sciences) paket programı ile bilgisayar ortamında değerlendirilmiştir. Verilerin analizinde sayı, yüzde, ortalama, standart sapma, 
$\mathrm{t}$ testi, tek yönlü varyans analizi (ANOVA) kullanılmıştır.

Araştırmanın Etik Yönü: Araştırmanın yapılabilmesi için etik onay, Hatay Mustafa Kemal Üniversitesi Tıp Fakültesi Girişimsel Olmayan Klinik Araştırmalar etik kurulundan alınmıştır (Tarih: 22/02/2018-Karar No:13). Araştırmanın yapıldı ğ kurumdan yazılı izin alınmış olup araştırma Helsinki Deklarasyonu Prensiplerine uygun olarak yapılmıştır. Araştırmaya katılan öğrencilerden yazılı ve sözel onam alınmıștır.

\section{BULGULAR VE TARTISSMA}

Öğrencilerin yaş ortalamas $120.59 \pm 1.5$ ' dir. Öğrencilerin \%71.2'sinin k1z, \%30.6'sinin 1 . sinıf, \% 28.1'inin ikinci sinıfta, \% 21.2'sinin 3 . sinıf, \%20'sinin 4. sinıf okuduğu, \%79.4'ünün çekirdek aile yapısına sahip, \%70.6'sının babasının çalıştığ $1, \quad \%$ 75.6'sının annesinin çalışmadığı saptanmıştır. Tablo 1'de öğrencilere ilişkin tanıtıcı özellikler verilmiştir.

Tablo 1. Öğrencilerin Tanıtıcı Özelliklerinin Dağılımı (N=320)

\begin{tabular}{lcc}
\hline Tanıtıcı Özellikler & $\mathbf{n}$ & $\mathbf{\%}$ \\
\hline Barınma yeri & 133 & 41.6 \\
Ailemle beraber & 129 & 40.3 \\
Yurtta & 58 & 18.1 \\
Arkadaşlarla bir evde & & \\
\hline
\end{tabular}

\begin{tabular}{lrr}
\hline $\begin{array}{l}\text { Hemşirelik mesleğini isteyerek seçme } \\
\text { durumu }\end{array}$ & \\
Evet & 171 & 53.4 \\
Hayır & 149 & 46.6 \\
\hline
\end{tabular}

\begin{tabular}{lcc}
\hline $\begin{array}{l}\text { Mezuniyet sonrası hemşirelik } \\
\text { yapmayı isteme durumu }\end{array}$ & \\
Evet & 246 & 76.9 \\
Hayır & 74 & 3.1 \\
\hline Düzenli ilaç kullanma durumu & & \\
Evet & 27 & 8.4 \\
Hayır & 293 & 91.6 \\
\hline Sürekli takip gerektiren hastalık durumu & \\
Evet & 20 & 6.2 \\
Hayır & 300 & 93.8 \\
\hline Sigara içme durumu & & \\
Evet & 56 & 17.5 \\
Hayır & 264 & 82.5 \\
\hline Alkol içme durumu & & \\
Evet & 83 & 25.9 \\
Hayır & 237 & 74.1 \\
\hline
\end{tabular}

Tablo 2. Öğrencilerin HESÖ ve BSÖ Toplam Puan Ortalamaları

\begin{tabular}{lcc}
\hline HESÖ & $\overline{\boldsymbol{X}} \pm$ SS & Min-Maks \\
\hline Ölçeği ve Alt Boyutları & & \\
Uygulama stresi & $31.3 \pm 8.7$ & $0-48$ \\
Akademik stresi & $32.1 \pm 9.1$ & $0-48$ \\
HESÖ Toplam Puan & $63.4 \pm 17.3$ & $0-96$ \\
\hline BSÖ & $\overline{\boldsymbol{X}} \pm \mathbf{S S}$ & Min-Maks \\
\hline Ölçeği ve Alt Boyutları & & \\
Problem çözme & $25.0 \pm 4.7$ & $11-33$ \\
Sosyal destek arama & $25.1 \pm 5.3$ & $11-33$ \\
Kaçınma & $24.2 \pm 5.3$ & $11-33$ \\
\hline
\end{tabular}

$\mathrm{Bu}$ araştırmada, hemşirelik mesleğine aday olan öğrencilerin HESÖ'den aldıkları toplam puan ortalamaları incelendiğinde; HESÖ ortalama puanının $63.4 \pm 17.3$ olduğu belirlenmiştir (Tablo 2). Ölçek alt boyut puanlarına baktığımızda akademik stres alt boyut puanının 32.1 \pm 9.1 ve uygulama alt boyutu puanının $31.3 \pm 8.7$ olduğu saptanmıştır. Buna göre hemşirelik eğitimi sırasında öğrencilerin yüksek düzeyde stres yaşadığı söylenebilir (Tablo 2). Çalışmamızın sonuçları, literatür ile paralellik göstermektedir $(16,7)$.

Ağaçdiken ve ark.'ın (2016) yaptıkları çalışmaya göre ölçek alt boyutlarından olan akademik stres alt boyut puanının $30.90 \pm 8.26$ ve uygulama alt boyutu puanının $31.82 \pm 8.57$ olduğu (17), öğrencilerin hemşirelik eğitiminin akademik ve uygulama boyutunda eşit düzeyde stres yaşadığı saptanmıştır. Belirtildiği gibi bu çalışmada ölçekten alınan maksimum puanlar incelendiğinde öğrencilerin stres düzeyinin en üst düzeye yakın olduğu görülmektedir. Güler ve Çınar'ın (2010) çalışmasında benzer şekilde öğrencilerin \% 65.8'inin eğitim ile ilgili; bu öğrencilerin \% 25.8'inin derslerle, \% 10'unun ise uygulama alanı ile ilgili stres yaşadığ belirlenmiştir (18).

$\mathrm{Bu}$ araştırmada, öğrencilerin BSÖ ölçeğinin alt boyutları incelendiğinde; "problem çözme" için 25.0土4.7, "sosyal destek arama" için $25.1 \pm 5.3$ ve "kaçınma" $24.2 \pm 5.3$ olduğu saptanmıştır (Tablo 2). Buna göre ölçekten alınan maksimum puanlar incelendiğinde öğrencilerin hemşirelik eğitimleri sırasında problem çözme, sosyal destek arama ve kaçınma davranışını kullandığ söylenebilir. 
Tablo 3. Öğrencilere İlişkin Bazı Özellikler ile HESÖ Puan Ortalamalarının Karşılaştırılması

\begin{tabular}{|c|c|c|c|c|}
\hline $\begin{array}{c}\text { Öğrencilere İlişkin } \\
\text { Özellikler }\end{array}$ & $\mathbf{n}$ & $\begin{array}{c}\text { Akademik stresi } \\
\text { (HESÖ alt boyutu) } \\
\text { X } \pm \text { SS }\end{array}$ & $\begin{array}{c}\text { Uygulama stresi } \\
\text { (HESÖ alt boyutu) } \\
\mathrm{X} \pm \mathrm{SS}\end{array}$ & $\begin{array}{c}\text { HESÖ Toplam } \\
\text { X } \pm \text { SS }\end{array}$ \\
\hline \multicolumn{5}{|l|}{ Cinsiyet } \\
\hline Kadın & 228 & $33.5 \pm 8.6$ & $32.6 \pm 8.3$ & $66.1 \pm 16.4$ \\
\hline \multirow[t]{2}{*}{ Erkek } & 92 & $28.6 \pm 9.3$ & $28.09 \pm 9.0$ & $56.7 \pm 17.7$ \\
\hline & & $\mathrm{t}=-4.450, \mathbf{p}=\mathbf{0 . 0 0 0}$ & $\mathrm{t}=-4.262, \mathbf{p}=\mathbf{0 . 0 0 0}$ & $\mathrm{t}=-4.509, \mathbf{p}=\mathbf{0 . 0 0 0}$ \\
\hline \multicolumn{5}{|l|}{ Yaş } \\
\hline 18-20 yaş & 152 & $32.5 \pm 9.1$ & $31,8 \pm 8,6$ & $64.3 \pm 17.2$ \\
\hline $21-24$ yaş & 168 & $31.7 \pm 9.0$ & $30,8 \pm 8,9$ & $62.6 \pm 17.4$ \\
\hline & & $\mathrm{t}=0.729, \mathrm{p}=0.467$ & $\mathrm{t}=0.974, \mathrm{p}=0.331$ & $\mathrm{t}=0.877, \mathrm{p}=0.381$ \\
\hline \multicolumn{5}{|l|}{ Sinıf } \\
\hline 1.Sinif & 98 & $31.7 \pm 9.2$ & $30.2 \pm 8.6$ & $62.0 \pm 17.2$ \\
\hline 2.Sinif & 90 & $34.1 \pm 8.2$ & $32.8 \pm 7.4$ & $67.0 \pm 15.1$ \\
\hline 3.Sinif & 68 & $32.0 \pm 8.8$ & $32.2 \pm 9.3$ & $64.2 \pm 17.8$ \\
\hline \multirow[t]{2}{*}{ 4.Sinif } & 64 & $29.7 \pm 9.8$ & $29.7 \pm 9.8$ & $59.4 \pm 18.9$ \\
\hline & & $\mathrm{F}=3.061, \mathbf{p}=\mathbf{0 . 0 2 8}$ & $\mathrm{F}=2.410, \mathbf{p}=\mathbf{0 . 0 6 7}$ & $\mathrm{F}=2.732, \mathrm{p}=\mathbf{0 . 0 4 4}$ \\
\hline \multicolumn{5}{|l|}{ Barınma yeri } \\
\hline Ailemle beraber & 133 & $31.9 \pm 9.9$ & $30.2 \pm 9.4$ & $62.2 \pm 18.9$ \\
\hline Yurtta & 129 & $32.4 \pm 8.5$ & $32.0 \pm 8.4$ & $64.4 \pm 16.4$ \\
\hline \multirow[t]{2}{*}{ Arkadaşlarla bir evde } & 58 & $31.7 \pm 8.2$ & $32.1 \pm 7.7$ & $63.8 \pm 17.3$ \\
\hline & & $\mathrm{F}=0.172, \mathrm{p}=0.842$ & $\mathrm{~F}=1.567, \mathrm{p}=0.210$ & $\mathrm{~F}=0.582, \mathrm{p}=0.559$ \\
\hline \multicolumn{5}{|c|}{ Hemşirelik mesleğini isteyerek seçme durumu } \\
\hline Evet & 171 & $30.3 \pm 9.5$ & $29.9 \pm 9.0$ & $60.2 \pm 17.9$ \\
\hline \multirow[t]{2}{*}{ Hayır } & 149 & $34.1 \pm 8.2$ & $32.9 \pm 8.1$ & $67.0 \pm 15.8$ \\
\hline & & $\mathrm{t}=-3.748, \mathbf{p}=\mathbf{0 . 0 0 0}$ & $\mathrm{t}=-3.082, \mathbf{p}=\mathbf{0 . 0 0 2}$ & $\mathrm{t}=-3.536, \mathbf{p}=\mathbf{0 . 0 0 0}$ \\
\hline \multicolumn{5}{|c|}{ Düzenli ilaç kullanma durumu } \\
\hline Evet & 27 & $31.0 \pm 7.1$ & $30.8 \pm 7.0$ & $61.8 \pm 13.5$ \\
\hline \multirow[t]{2}{*}{ Hayır } & 293 & $32.2 \pm 9.2$ & $31.3 \pm 8.9$ & $63.5 \pm 17.6$ \\
\hline & & $\mathrm{t}=-0.638, \mathrm{p}=0.524$ & $\mathrm{t}=-0.303, \mathrm{p}=0.762$ & $\mathrm{t}=-0.489, \mathrm{p}=0.625$ \\
\hline
\end{tabular}

Ekinci ve ark. (2013) yaptığı çalışmada problem çözme $27.23 \pm 4.08$, sosyal destek arama 26.28 \pm 4.06 , kaçınma $24.36 \pm 4.01$ olarak belirlenmiş olup (19) bu çalışmanın bulgusuyla benzerlik göstermektedir. Bu çalışmada, kız öğrencilerin sosyal destek arama ve kaçınma yöntemini erkek öğrencilerden daha fazla kullandığ 1 ve kız öğrencilerin stresle baş etmede sosyal destek alma eğiliminde olduğu belirlenmiştir. Literatür, bu araştırmanın sözü edilen bulgusuyla benzerlik göstermektedir (20). Cinsiyetin, stres ve stres ile başa çıkma yöntemlerinde etkin bir faktör olduğu ve genellikle stresle baş etme yöntemlerinin kız ve erkeklerde farklı olduğu görülmektedir $(21,22)$. Bununla birlikte, stres durumunda stresle baş etme yönteminin aynı olduğunu bildiren çalışmalar da bulunmaktadır $(19,23)$. Çalışmalardaki farklılıklar ele alınan örneklemin stres kaynağ 1 , akademik durum ve kişilik özellikleri gibi pek çok faktörden kaynaklı olabilir (23).
Cinsiyeti kadın, ikinci sınıfta olan ve hemşirelik mesleğini isteyerek seçmeyen öğrencilerin HESÖ ortalama diğerlerine göre yüksek olduğu ve istatistiksel olarak anlamlı fark olduğu bulunmuştur $(\mathrm{p}<0.05)$ (Tablo 3$)$. Yaş, barınma ve düzenli ilaç kullanma durumlarının öğrencilerin stres düzeylerini etkilemediği belirlenmiştir ( $p>0.05)$.

Kız çocuklarının aile ortamında daha fazla zaman geçirmesi ve dolayısıyla aileye daha bağımlı olmaları nedeniyle üniversite zamanında aile ortamından çıkmaları, adaptasyon sorunları yaşamalarına ve bu durumunda öğrencinin stres durumunu arttırmış olabileceğini düşündürmektedir (24). Araştırma bulgusu Singh ve arkadaşlarının yaptığı araştırma bulgusu ile benzerlik gösterirken hemşirelik öğrencilerinin ilk klinik deneyim sırasındaki stres düzeylerinin incelenmesi başlıklı çalışmaya göre benzerlik göstermemektedir $(16,25)$. 
Tablo 4. Öğrencilere İlişkin Bazı Özellikler ile BSÖ Puan Ortalamalarının Karşılaştırılması

\begin{tabular}{|c|c|c|c|c|}
\hline $\begin{array}{c}\text { Öğrencilere İlişkin } \\
\text { Özellikler }\end{array}$ & $\mathbf{n}$ & $\begin{array}{c}\text { Problem çözme } \\
\text { (BSÖ alt boyutu) } \\
\text { X } \pm \text { SS } \\
\end{array}$ & $\begin{array}{c}\text { Sosyal destek arama } \\
\text { (BSÖ alt boyutu) } \\
\mathrm{X} \pm \mathrm{SS} \\
\end{array}$ & $\begin{array}{c}\text { Kaçınma } \\
\text { (BSÖ alt boyutu) } \\
\mathrm{X} \pm \mathrm{SS} \\
\end{array}$ \\
\hline \multicolumn{5}{|l|}{ Cinsiyet } \\
\hline Kadın & 228 & $25.3 \pm 4.9$ & $25.6 \pm 4.6$ & $24.8 \pm 5.1$ \\
\hline \multirow[t]{2}{*}{ Erkek } & 92 & $24.3 \pm 4.0$ & $23.4 \pm 6.7$ & $22.8 \pm 5.4$ \\
\hline & & $\mathrm{t}=-1.782, \mathrm{p}=0.076$ & $\mathrm{t}=-3.370, \mathbf{p}=\mathbf{0 . 0 0 1}$ & $\mathrm{t}=-2.960, \mathbf{p}=\mathbf{0 . 0 0 3}$ \\
\hline \multicolumn{5}{|l|}{ Yaş } \\
\hline $18-20$ yaş & 152 & $25.7 \pm 4.9$ & $25.9 \pm 5.5$ & $25.4 \pm 5.4$ \\
\hline $21-24$ yaş & 168 & $24.4 \pm 4.3$ & $24.2 \pm 5.1$ & $23.2 \pm 5.0$ \\
\hline & & $\mathrm{t}=2.489, \mathbf{p}=\mathbf{0 . 0 1 3}$ & $\mathrm{t}=2.819, \mathbf{p}=\mathbf{0 . 0 0 5}$ & $\mathrm{t}=3.739, \mathbf{p}=\mathbf{0 . 0 0 0}$ \\
\hline \multicolumn{5}{|l|}{ Sinıf } \\
\hline 1.Sinıf & 98 & $27.0 \pm 3.6$ & $26.0 \pm 5.7$ & $25.7 \pm 5.5$ \\
\hline 2.Sinif & 90 & $23.6 \pm 5.4$ & $25.2 \pm 4.7$ & $25.3 \pm 4.5$ \\
\hline 3.Sinif & 68 & $25.0 \pm 4.2$ & $24.1 \pm 5.4$ & $22.1 \pm 4.7$ \\
\hline \multirow[t]{2}{*}{ 4.Sinıf } & 64 & $24.0 \pm 4.5$ & $24.0 \pm 5.6$ & $22.6 \pm 5.4$ \\
\hline & & $\mathrm{F}=10,511, \mathbf{p}=\mathbf{0 , 0 0 0}$ & $\mathrm{F}=2.328, \mathrm{p}=0,075$ & $\mathrm{~F}=10,235, \mathbf{p}=\mathbf{0 , 0 0 0}$ \\
\hline \multicolumn{5}{|l|}{ Barınma yeri } \\
\hline Ailemle beraber & 133 & $24.6 \pm 4.9$ & $25.0 \pm 4.4$ & $24.7 \pm 5.0$ \\
\hline Yurtta & 129 & $25.7 \pm 4.3$ & $25.2 \pm 6.0$ & $24.4 \pm 5.5$ \\
\hline \multirow[t]{2}{*}{ Arkadaşlarla bir evde } & 58 & $24.6 \pm 4.7$ & $24.5 \pm 5.8$ & $22.6 \pm 5.0$ \\
\hline & & $\mathrm{F}=1.890, \mathrm{p}=0.153$ & $\mathrm{~F}=0.383, \mathrm{p}=0.682$ & $\mathrm{~F}=3.432, \mathbf{p}=\mathbf{0 . 0 3 4}$ \\
\hline \multicolumn{5}{|c|}{ Hemşirelik mesleğini isteyerek seçme durumu } \\
\hline Evet & 171 & $24.2 \pm 5.9$ & $23.3 \pm 4,2$ & $23.1 \pm 3.7$ \\
\hline \multirow[t]{2}{*}{ Hayır } & 149 & $22.9 \pm 5.0$ & $22.3 \pm 4.9$ & $22.9 \pm 4.2$ \\
\hline & & $\mathrm{t}=2.896, \mathbf{p}=\mathbf{0 . 0 0 4}$ & $\mathrm{t}=2.681, \mathbf{p}=\mathbf{0 . 0 0 8}$ & $\mathrm{t}=0.865, \mathrm{p}=0.387$ \\
\hline \multicolumn{5}{|c|}{ Düzenli ilaç kullanma durumu } \\
\hline Evet & 27 & $25.4 \pm 5.1$ & $25,3 \pm 4,2$ & $23.1 \pm 6.3$ \\
\hline \multirow[t]{2}{*}{ Hayır } & 293 & $25.0 \pm 4.6$ & $24.9 \pm 5.4$ & $24.3 \pm 5.2$ \\
\hline & & $\mathrm{t}=0.362, \mathrm{p}=0.718$ & $\mathrm{t}=0.347, \mathrm{p}=0.729$ & $\mathrm{t}=-1.107, \mathrm{p}=0.269$ \\
\hline
\end{tabular}

Literatüre göre öğrencilerin, klinik eğitim sürecince stres yaşadığı belirtilirken, klinik yeterliliklerinin de yetersiz olduğu düşünceleri klinik stres yaşamalarına neden olabilmektedir (16, 26). Ağaçdiken ve arkadaşlarının (2016) yaptıkları araştırmada birinci sınıftaki öğrencilerin ölçek toplam puan ortalamasının $65.62+12.66$ ile orta düzeyin üstünde olduğu belirlenmiștir (17). Sheu ve arkadaşlarının (2002) hemşirelik birinci sınıf öğrencileri ile yaptıkları çalışmada öğrencilerin yeterli bilgiye sahip olmamaları ve hasta bakım becerilerinin tam olarak gelişmemesi sebebiyle stres yaşadıklarını saptanmıştır (27). Bu araştırmada birinci sınıf öğrencilerinin ağırlıklı teorik ve uygulamada gözlem yaptıkları dolayısıyla ikinci sınıf öğrencilerinin uygulamaya başladıkları için birinci sınıfa göre stres düzeylerinin daha yüksek olduğunu düşündürebilir.

Melincavage (2011) hemşirelik öğrencilerinin klinik stres düzeylerini araştırdığ1 çalışmasında klinik uygulamada öğrencilerin karşılaştığı stresörlerin hemşireler, sorumlu ögretim eleman1, doktorlar, hasta ve hasta yakınları olduğunu belirlemiştir (3). Benzer şekilde Elçigil ve Sarı (2011) yaptığı araştırmada, öğrenci hemşirelerin en fazla klinikte bulunan hemşire ve doktorlar, sorumlu öğretim elemanı nedeniyle stres yaşadıklarını belirlemiştir (28). Ayrica hata yapma korkusu da klinik uygulamada öğrencilerin karşılaştığ 1 stresörler arasındadır.

$\mathrm{Bu}$ çalışmada ikinci sınıf öğrencilerinin klinik stresi yoğun bir şekilde yaşadığ 1 ve sınıflar arasındaki farkın istatistiksel olduğu belirlenmiştir. $\mathrm{Bu}$ durumun, ikinci sınıf öğrencilerinde gözlemden uygulamaya doğru ilk klinik deneyimi yaşamaları sebebiyle literatürde belirtilen stresörlerle ilk kez karşılaşmalarından kaynaklandığı ve bu nedenle klinik öğretimin amacına ulaşmasını olumsuz yönde etkileyeceği düşünülmektedir (17). Ayrıca yüksek stres öğrencilerin düşünme mekanizmalarını olumsuz etkileyip akademik başarısını düşürmektedir (29). $\mathrm{Bu}$ durumda öğrencide hipertansiyon, immun yetmezlik vb. hastalıklara neden olarak öğrencilerin eğitimlerinden beklenen düzeyde yararlanamamasina neden olmaktadır $(5,30)$. 
Literatürde yapılan çalışmalar araştırma bulgumuzu desteklemektedir $(25,31)$.

Yaş1 18-20 grubunda olan, birinci sınıfta olan, hemşirelik mesleğini isteyerek seçen öğrencilerin problem çözme davranışını; cinsiyeti kadın olan, 18-20 yaş grubunda olan, hemşirelik mesleğini isteyerek seçen öğrencilerin sosyal destek arama davranışını; cinsiyeti kadın olan, 1820 yaş grubunda olan, birinci sınıfta olan, ailesiyle beraber yaşayan öğrencilerin kaçınma davranışını kullandığ1 ve BSÖ alt boyut ortalama puanının daha yüksek olduğu bulunmuştur $(\mathrm{p}<0.05)$ (Tablo 4).

$\mathrm{Bu}$ durum, 18-20 yaş grubu ve birinci sınıf da olan öğrencilerin probleme yönelik çözüm yöntemlerini ve başkalarından destek arama davranışlarını daha fazla gösterdiklerini düşündürmektedir. Ayrıca, 18-20 yaş grubu ve birinci sınıfta olan öğrencilerin, üniversite hayatına başlama aşamasına geldiklerinde, aile dışında tek başlarına mücadele çabalarının yoğunlaştı̆̆1, sosyalleşmesinin arttığ1, aileden bağımsızlaşarak daha fazla özerk olduğu ve birçok zorluklarla baş ettikleri dönem olduğu düşünülmektedir $(32,33)$.

Araştırmamızda ailesiyle beraber yaşayan öğrencilerin, BSÖ kaçınma alt boyut ortalama puanının daha yüksek olduğu belirlenmiştir (p<0.05) (Tablo 4). Bu durum, anne babalariyla birlikte yaşayan öğrencilerin, günlük yaşamda karşılaştıkları problemlerin üstesinden aileleri ile birlikte geldikleri bu nedenle problemi görmezlikten gelme ve başka şeylerle ilgilenip problemin kaynağından uzaklaşma gibi durumların meydana geldiğini düşündürebilir. Diğer yönden bu gibi alışma durumlarında, aile

\section{KAYNAKLAR}

1. Şimşekoğlu N, Mayda AS. Bir Üniversite Hastanesinde Görevli Hemşirelerin Sağlıklı Yaşam Biçimi Davranışları ve Sağlık Kaygısı Düzeyleri. Düzce Üniversitesi Sağlı Bilimleri Enstitüsü Dergisi 2016;6(1): 19-29.

2. Doğan B, Eser $M$. Üniversite Öğrencilerinin Stresle Başa Çıkma Yöntemleri: Nazilli MYO Örneği. EJOVOC: Electronic Journal of Vocational Colleges, 2013; 3(4):29-39.

3. Melincavage SM. Student Nurses' Experiences of Anxiety in The Clinical Setting. Nurse Education Today 2011; 31(8):785-9.

4. Moridi G, Khaledi S, Valiee S. Clinical Training Stress-İnducing Factors From The Students' Viewpoint: A Questionnaire-Based Study. Nurse Education in Practice 2014; 14(2):160-3.

5. Karaca A, Yıldırım N, Ankaralı H, Açıkgöz F, Akkuş A. Hemşirelik Eğitimi Stres Ölçeği'nin desteğinin stresle başa çıkmada önemli olduğu vurgulanmaktadir (9).

Araştırmanın Sınırlılıkları: Araştırma bulguları sadece araştırmanın uygulandığı yüksekokul öğrencilerine genellenebilir ve araştırmaya katılmayı kabul eden öğrencilerin verileri ile sinırlidir.

\section{SONUÇ VE ÖNERILER}

$\mathrm{Bu}$ araştırma sonucunda hemşirelik öğrencilerinin stres düzeyinin en üst düzeye yakın olduğu görülmektedir. Bu bulgular doğrultusunda öğrencilerin kültürel tutum ve özellikleri göz önünde bulundurularak hemşirelik eğitimindeki stresörlerin belirlenmesi ve öğrenciyi güçlendirmeye yönelik stres ile baş etme yöntemleri, sosyal faaliyetleri arttıracak ders diş1 sosyal etkinlikler düzenlenerek öğrencilerin sosyal desteklerinin arttırılması son derece önemli gereksinimlerdir. Ayrıca, uygulama ve eğitim öncesi öğrencilere oryantasyon programlarının düzenlenmesi ve öğrencilerin kendilerini hemşirelik aktivitelerinde yetersiz hissetmemeleri için uygulama ile ilgili yeterli olmadıklarını düşündükleri konularda eğitim verilmesi, hemşirelik okullarında simülasyon laboratuvarları kurularak öğrenciye simülasyon eğitimi verilmesi önerilmektedir.

Çıkar Tartışması: $\mathrm{Bu}$ çalışmada yazarlar arasında herhangi bir çıkar tartışması yoktur.

Yazar Katkısı: Tüm yazarlar araştırmanın planlanmas1, verilerin analizi, yorumlanmas1, makalenin hazırlanması, gözden geçirilmesi ve son halinin verilmesine katkı sağlamıştır.

Teşekkür: $\mathrm{Bu}$ çalışmanın gerçekleşmesinde katkıları bulunan öğrencilere teşekkür ederiz.

Türkçeye uyarlanması. Hemşirelikte Araştırma Geliştirme Dergisi 2014; 16(2): 29-40.

6. Suresh P, Matthews A, Coyne I. Stress And Stressors in The Clinical Environment: A Comparative Study of Fourth-Year Student Nurses And Newly Qualified General Nurses in Ireland. Journal of Clinical Nursing 2012; 22(56): 770-9.

7. Baysan Arabacı L, Akın Korhan E, Tokem Y, Torun R. Hemşirelik Birinci Sınıf Öğrencilerinin İlk Klinik Deneyim Öncesi-Sırası ve Sonrası Anksiyete ve Stres Düzeyleri ve Etkileyen Faktörler. Hacettepe Üniversitesi Hemşirelik Fakültesi Dergisi 2015;1(2):1-16.

8. Jimenez C, Navia-Osorio P, Vacas Diaz C. Stress And Health in Novice And Experienced Nursing Students. Journal of Advanced Nursing 2010; 66 (2): 442-55. 
9. Luo Y, Wang H. Correaltion Research On Psychologicial Health İmpact on Nursing Students Against Stres, Coping Way And Social Support. Nurse Education Today 2009;29(1):5-9.

10. Timmins F, Corroon AM, Byrne G, Mooney B. The Challenge of Contemporary Nurse Education Programmes. Perceived Stressors of Nursing Students: Mental Health And Related Lifestyle İssues. Journal of Psychiatric and Mental Health Nursing 2011;18(9):758-66.

11. Kara D. Eğitim-Öğretim Yaşantısında Stres Yaratan Faktörler ve Aile Özelliklerine Göre Öğrencilerin Stresle Başa Çıkma Davranışlarının İncelenmesi. Selçuk Üniversitesi Sosyal Bilimler Enstitüsü Dergisi. 2009;22:255-63.

12. Ergin E.,Çevik K, Pakiş Çetin S. Hemşirelik Öğrencilerinin Eğitimlerine İliş̧in Algıladığ Stres ve Stresle Baş Etme Davranışlarının İncelenmesi Hemşirelikte Eğitim ve Araştırma Dergisi 2018;15(1):16-22.

13. Gray-Toft P, Anderson J. The Nursing Stress Scale: Development of an Instrument. Journal of Behavioural Assessment 1981;3(1):11-23 içinde Rhead, M., 1995. Stress among Student Nurses: Is It Practical or Academic? Journal of Clinical Nursing 1981;4(6):369-76.

14. Amirkhan JH. A Factor Analytically Derived Measure of Coping: The Coping Strategy Indicator. Journal of Personality and Social Psychology, 1990;59(5):1066-74.

15. Aysan F. Başa Çıkma Stratejisi Ölçeğinin Türkçe Formunun Oluşturulması. Ege Eğitim Dergisi 2003;1(3):123-32.

16. Taşdelen S, Zaybak A. Hemşirelik Öğrencilerinin İlk Klinik Deneyim Sirasındaki Stres Düzeylerinin İncelenmesi. Florence Nightingale Hemsirelik Dergisi 2013; 21(2): 101-6.

17. Ağaçdiken S, Mumcu Boğa N, Özdelikara A. Hemşirelik Öğrencilerinin Hemşirelik Eğitimine Yönelik Yaşadıkları Stres Düzeyinin Belirlenmesi. Samsun Sağl1k Bilimleri Dergisi 2016;1 (1): 25 - 41.

18. Güler Ö, Çınar S. Hemşirelik Öğrencilerinin Algıladıkları Stresörler ve Kullandıkları Baş etme Yöntemlerinin Belirlenmesi. Maltepe Üniversitesi Hemşirelik Bilim ve Sanatı Dergisi Sempozyum Özel Sayısı 2010;253-60

19. Ekinci M, Şahin Altun Ö, Can G. Hemşirelik Öğrencilerinin Stresle Başa Çıkma Tarzları ve Atılganlık Düzeylerinin Bazı Değişkenler Açısından İncelenmesi. Psikiyatri Hemşireliği Dergisi 2013;4(2):67-74.

20. Aşçı Ö, Hazar G, Kılıç E, Korkmaz A. Üniversite Öğrencilerinde Stres Nedenlerinin ve Stresle Başa Çıkma Biçimlerinin Belirlenmesi. Uşak Üniversitesi Sosyal Bilimler Dergisi 2015; 8(4): $213-32$.
21. Çelik SB. Orta Asya Türk Cumhuriyetlerinden Gelen Öğrenciler ile Türkiye Cumhuriyeti Öğrencilerinin Stresle Başa Çıkma Stratejilerinin Karşılaştırılması. Ahi Evran Üniversitesi Kırşehir Eğitim Fakültesi Dergisi 2008;9(3):125-32.

22. Savcı M, Aysan F. Üniversite Öğrencilerinde Algılanan Stres Düzeyi ile Stresle ile Başa Çıkma Stratejileri Arasındaki İlişki. Uluslararası Türk Eğitim Bilimleri Dergisi 2014;3: 44-56.

23. Taşkın Ö, Çağlayan HS. Beden Eğitimi ve Spor Öğretmenliği Bölümü Öğrencilerinin Stresle Başa Çıkma Tarzlarının İncelenmesi. Ulusal Beden Eğitimi ve Spor Öğretmenliği Kongresi, Van/Yüzüncü Y1l Üniversitesi Eğitim Fakültesi Dergisi Özel Sayısı 2011;73-82.

24. Altıok Öner H, Üstün B. Hemşirelik Öğrencilerinin Stres Kaynakları. Kuram ve Uygulamada Eğitim Bilimleri 2013;13(2):74766.

25. Singh A, Chopra M, Adiba S, Mithra P, Bhardwaj A, Arya R, et al. A Descriptive Study of Perceived Stress Among the North Indian Nursing Undergraduate Students. Iranian Journal of Nursing and Midwifey Research. 2013;18(4):340-2.

26. Atay S, Yılmaz F. Sağlık Yüksekokulu Öğrencilerinin İlk Klinik Stres Düzeyleri. Anadolu Hemşirelik ve Sağlık Bilimleri Dergisi 2011; 14(4): 32-7.

27. Sheu S, Lin HS, Hwang S-Li. Perceived Stres and Physio-Psycho- Social Status of Nursing Students During Their İnitial Period of Clinical Practice: The Effect of Coping Behaviors. International Journal of Nursing Studies 2002; 39(2):165-75.

28. Elçigil A, Sarı HY. Facilitating Factors in Clinical Education in Nursing. Dokuz Eylül Üniversitesi Hemşirelik Yüksek Okulu Elektronik Dergi 2011;4(2): 67-71.

29. Maville JA, Kranz PL, Tucker BA. Perceived Stress Reported By Nurse Practitioner Students. Journal of the American Association of Nurse Practitioners 2004;16(6):257-62.

30. Lee M, Holzemer W, Faucett J. Psychometric Evaluation of the Nursing Stress Scale (NSS) Among Chinese Nurses in Taiwan. Journal of Nursing Measurement 2007;15(2):133-44.

31. Sharif F, Masoumi S. A Qualitative Study Of Nursing Student Experiences of Clinical Practice. Bio Med Central Nursing. 2005;4(6):1-7.

32. Aladağ M. Üniversiteye Uyum Konusunda Yürütülen Akran Danışmanlığı Programının Değerlendirilmesi. Türk Psikolojik Danışma ve Rehberlik Dergisi 2009; 4(31): 12-22.

33. Pittman LD, Richmond A. University Belonging, Friendship Quality and Psychological Adjustment During the Transition to College. The Journal of Experimental Education 2008; 76(4): 343-61. 